\title{
VIEWS ON THE OFFENCE OF HUMAN TRAFFICKING
}

\section{V.A. PORUMB}

\section{VLAD-ALEXANDRU PORUMB}

Ministry of Internal Affairs

E-mail: porumbvladalexandru@yahoo.ro

\section{ABSTRACT}

In the international background of the current period, Romania is included in the "Balkan Route" of illegal migration, which influences all the main areas of society, including the security of the state and that of its citizens.

One of the main issues in the last decade, at national and international level, is the human trafficking, linked to the illegal migration, which is constantly increasing.

Human trafficking is an offense which affects human rights, with profound economic and social interference, due to the mobility and perceivable advantages of the phenomenon.

Until 2014, human trafficking was provided for by law 678/2001 regarding the prevention and control of human trafficking, but with the entry into force of the New Criminal Code this offense was covered by the same code, provided by art. $210 .^{1}$

KEY WORDS: human trafficking, security, phenomenon.

\section{INTRODUCTION}

The phenomenon of human trafficking is not an isolated phenomenon,specific to our country; it has an international and cross-border characterand is part of what we call organized crime.

The concept of trafficking is not new and was first used in the 16th century as a synonym for trade; therefore this term has no negative connotations. However, towards the 17th century, trafficking began to be associated with the illicit or illegal sale of goods.

Although initially trafficking was largely understood as the sale of drugs and weapons in the 19th century, this term also included the trading of people considered goods and sold in slavery.

This slave trade was outlawed towards the end of the 19th century. At the beginning of the 20th century, the term "trafficking" often referred to the "white slave trade", which was the cross-border movement of women and children for prostitution purposes. Only in the late 1990s trafficking was associated with the prostitution and sexual exploitation of women and children.

Prostitution is considered one of the oldest "jobs in the world". Myths or historical testimonies show that in ancient times prostitution was not only eradicated but even encouraged for various purposes. ${ }^{2}$

It should be noted that a number of important UN documents have referred to the prohibition of human trafficking. We can enumerate the Universal Declaration of Human Rights (1948), the International Covenant on Civil and Political Rights (1966), The

\footnotetext{
${ }^{1}$ Romanian Criminal Code - Special Section - Title VII - Trafficking and exploitation of vulnerable people

${ }^{2}$ M.Focault ,The History of sexuality, vol. 3 , Univers edition, Bucharest, 2005 , p.57.
} 


\section{Vlad-Alexandru Porumb}

International Covenant on Economic, Social and Cultural Rights (1966), the Council of Europe Convention on Action against Trafficking in Human Beings (2005). ${ }^{3}$

Romania not only complied with all these international documents, but also adopted a law in accordance with them, being able to effectively control this phenomenon.

In this respect, among the adopted internal regulations we mention: Law no. 678/2001 regarding the prevention and control of human trafficking ${ }^{4}$ and the Regulation on the application of this law, approved by the Government Decision no. 299/20035, Law no. 682/2002 on the protection of witnesses ${ }^{6}$, Law no. 39/2003 regarding the prevention and control of organized crime ${ }^{7}$, Law no. 211/2004 regarding certain measures for insuring the protection of victims of this offence ${ }^{8}$, Law no. 272/2004 regarding the protection and promotion of child rights ${ }^{9}$ and Law no. 302/2004 regarding the international legal cooperation in criminal matters ${ }^{10}$.

By Government Decision no. 1584/2005 was established the National Agency against Human Trafficking ${ }^{11}$; the need to establish this unit was required by the magnitude of human trafficking, which is a cause for concern for most of the world's states.

\section{ANALYSIS OF THE HUMAN TRAFFICKING OFFENCE}

The legal framework of the human trafficking offense is provided in the Criminal Code - Special Part - Title VII - Trafficking and exploitation of vulnerable people, art. 210.

The special legal object represents the social relations whose development is conditioned by the meeting of the human freedom and rights, dignity, physical integrity or health against the exploitation and transformation of the person into a source of gain.

The material object is the body of the trafficked person for exploitation ${ }^{12}$.

The active subject can be any responsible person. In the worse version, the active subject is qualified, having the status of civil servant.

The passive subject is the trafficked person for the purpose of exploitation. The passive subject can be any person, woman or man. When the passive subject is a person under the age of 18, the offense transforms, from human trafficking into trafficking of minors.

The material element of the objective side is in the form of a plurality of alternative actions which can be accomplished by five distinct ways, namely recruiting, transporting, transferring, housing and receiving a person.

The first way of committing a trafficking offense is the recruitment action.

Recruitment means the action of attracting, persuading potential victims of human trafficking for the purpose of their exploitation.

Recruitment methods and techniques vary according to the degree of vulnerability of the victim, the level of training, material status, life experience, all speculated by traffickers. Therefore, the main recruitment means consisted of: Promoting honest and well paid jobs in

\footnotetext{
${ }^{3}$ C. Barsan, European Convention of Man's Rights. Remarks on articles, vol. I, Rights and freedom, All Beck ed., Bucharest, 2007, p.139.

${ }^{4}$ The Official Gazette of Romania no. 783 from $11^{\text {th }}$ of December 2001

${ }^{5}$ The Official Gazette of Romania no. 206 from $31^{\text {st }}$ of March 2003

${ }^{6}$ The Official Gazette of Romania no. 964 from $28^{\text {th }}$ of December 2002

${ }^{7}$ The Official Gazette of Romania no. 50 from $29^{\text {th }}$ of January 2003

${ }^{8}$ The Official Gazette of Romania no. 505 from $4^{\text {th }}$ of June 2004

${ }^{9}$ The Official Gazette of Romania no. 557 from $28^{\text {th }}$ of June 2004

${ }^{10}$ The Official Gazette of Romania no. 594 from $1^{\text {st }}$ of July 2004

${ }^{11}$ The Official Gazette of Romania no. 5 from $4^{\text {th }}$ of January 2004

${ }^{12}$ I. Lascu, Indictments regarding human trafficking, in RDP (Criminal Law Magazine) no. 3/2002, p. 65.
} 


\section{VIEWS ON THE OFFENCE OF HUMAN TRAFFICKING}

developed countries, made directly by the trafficker or by relatives close to the victim; advertisements in newspapers on highly attractive job offers abroad; ads by matrimonial agencies, where victims, especially women, are attracted to marry with foreign citizens ${ }^{13}$; through the Internet, usually through social networks.

The second way to commit a human trafficking offense is transport.

Leading involves transporting trafficked persons from one place to another, either domestically or abroad, with different means of transport, for the purpose of exploitation.

The transport operation may be organized by the person recruiting the trafficked person, other persons or traffickers.

The third way of committing a trafficking offense is the transfer action.

In ordinary language, transfer represents something that moves from one place to another, both fictitious and material ${ }^{14}$. For the purposes of the offense, transfer means the transfer of human trafficking between traffickers through the sale, exchange, hiring, assigning or other illegal transactions for the purpose of the person's exploitation.

Victims realize that they have been sold only when they are dispossessed of their identity documents, taken in isolated and permanently supervised places where they are not informed, are not allowed to come into contact with others, and are subjected to dehumanizing treatments making them vulnerable and easy to exploit.

The fourth way of committing a human trafficking offense is the housing action. Housing means installing, setting up, temporarily arranging a trafficked person in a house or in a location with the same destination (motel, hotel, camping) for the purpose of exploitation. The last way of committing the offense is the receiving action, which is accomplished by taking over the trafficked victim by another trafficker following the purchase, exchange or other similar means for exploitation.

For the existence of the offense, with regard to the material element of the objective part, in any of the five ways analyzed, the following conditions must be met:

\section{A - EXPLOITATION OF A PERSON}

According to art. 182 of the Criminal Code, the exploitation of a person means:

a) requiring the person to execute a job or to perform services in a forced manner.

b) keeping the person in the state of slavery or other similar procedures of deprivation of liberty or servitude.

c) forcing the person to perform prostitution, pornography in order to produce and broadcast pornographic materials or other forms of sexual exploitation.

In the case of human trafficking, victims are first recruited in different forms and ways, after which they are forced to prostitute or willingly accept this because they are threatened, beaten, left without money, without documents, in a foreign country where they do not know the language, and no other person to help them, so they eventually agree to prostitute. Traffickers take all the money they earn from this activity.

"Pornography" means the act of adults, as well as materials that produce or disseminate such acts.

d) requiring the person to practice begging.

(e) removal of organs, tissues or cells of human origin, unlawfully.

\footnotetext{
${ }^{13}$ Gh. Mateuț, V.E. Petrescu, N. Ștefăroi, A. Prună, C. Luca, Human trafficking. Offender. Victim. Offence. Social Alternative Association ed., Iași, 2005, p. 41.

${ }^{14}$ Romanian Explanatory Dictionary, II ${ }^{\text {nd }}$ ed., EnciclopedicUnivers ed., Bucharest, 1996
} 


\section{Vlad-Alexandru Porumb}

These forms of exploitation involve the trafficking of victims by traffickers, as they are caused by the constraint of committing different offences in the interest of trafficked people ${ }^{15}$

\section{B- THE ACTIONS INCRIMINATED IN LAW MUST BE COMMITTED IN ONE OF THE FOLLOWING WAYS:}

a) Threat - This means that a victim feels that he/she or others close to him/her will have serious consequences if he/she does not respond to the traffickers' demands.

For example, victims are threatened with the death, mutilation, kidnapping of a family member. Legal practice has shown that even violence can be a threat to the victim: the breaking of ties with the destruction of things by the victim, the violent destruction of property in front of the victim; all of which have an intimidating effect on the victim and are likely to destroy and exert a strong moral constraint on the victims ${ }^{16}$.

b) Violence - Violence was defined as any form of physical aggression used against a person consisting of acts of attack, immobilization, association, including damages to the nature of the offense provided by article 193 of the Criminal Code ${ }^{17}$.

c) abduction represents the action of traffickers to take the victim out of his/her environment, either by force, by attracting and depriving him/her of freedom.

d) fraud - Fraud is the action of traffickers to mislead the victims of human trafficking in order to gain advantages in violation of their rights.

e) deception - is the presentation as true of a false act or as a liar of a true action by the traffickers of the victim. For example, promises to victims of paid jobs abroad in connection with their training, extremely accessible working conditions, marriages with rich foreigners.

Immediate result. The action of the active subject must result in a state of danger that has been created for the relations regarding the freedom of the person, meeting the rights of the person, the physical and psychic integrity of the person and which is accomplished by the incriminated activity itself.

Causality report. There must be a causal link between the perpetrator's action and the immediate result; this is accomplished by the very act describing the act of incrimination.

Regarding the subjective side of human trafficking, this is generally done in the form of direct intent.

Therefore, in all the ways of existence of the material element for the offence of human trafficking, the law requires the existence of a specific purpose of the offence, namely the exploitation of the victim, as being an essential condition, whether the purpose pursued was accomplished or not.

In the situation of achieving this purpose, there is a real offense race between human trafficking and the offence which forms the purpose of exploitation (for example: promoting prostitution - article 213 of the Criminal Code), of course, if both the trafficking activity and the subsequent exploitation activity is done by the same person.

There is also an appeal in the interest of the law in which the supreme court established the relationship between the offence of human trafficking and promoting prostitution in the regulation prior to the adoption of the current Criminal Code. ${ }^{18}$

\footnotetext{
${ }^{15}$ Gh. Mateut, V.E. Petrescu, N. Ștefăroi, A. Prună, C. Luca, Human trafficking. Offender. Victim. Offence. Social Alternative Association ed., Iași, 2005, p. 58.

${ }^{16}$ I. Gârbuleț, Human trafficking, UniversulJuridic ed., Bucharest, 2010, p. 52

${ }^{17}$ G. Antoniu, Remarks in the Criminal Code. Special section. ȘtiințificășiEnciclopedică ed., Bucharest, 1975, vol. I, p. 191
} 


\section{VIEWS ON THE OFFENCE OF HUMAN TRAFFICKING}

\section{DISTINCTIONS BETWEEN HUMAN TRAFFICKING AND PROSTITUTION}

According to art. 213 of the Penal Code, paragraph 1 "Determining or facilitating the practice of prostitution or obtaining patrimonial benefits from the practice of prostitution by one or more people shall be punished by imprisonment from 2 to 7 years and the prohibition of exercising certain rights."

In the same article, par. 2 states that "If the determination to start or continue to practice prostitution was made by constraint, the punishment shall be imprisonment from 3 to 10 years and the prohibition of exercising certain rights."

A first distinction between the two offenses is the generic legal object.

The offense of human trafficking has as its generic legal object the right to freedom of will and action pertaining to each person. ${ }^{19}$

In the case of the offense of promoting prostitution, the socially protected value resides precisely in the good morals in the relations of social coexistence and illicit insurance of livelihoods.

The second distinction between the two offences is based on the material element of the objective side. In the simplest form, the offense of promoting prostitution is carried out under the aspect of the material element of the objective side, by the following means: determining, facilitating the practice of prostitution, or benefiting from prostitution, ways that the offence of human trafficking does not regulate.

In the case of promoting prostitution, it is not necessary to carry out constraints on the victim or to subject them to pressure from a person who has gained authority over him/her, except for the means of constraining to practice prostitution.

The third distinction between the two offences takes into account the subjective side. In this respect, the offence of human trafficking is committed with purpose-oriented intent, and in the case the offence of promoting prostitution, the offense can be committed with a direct or indirect intention, the purpose or the action is not interested in the existence of the will, and can only be considered at the legal individualization of the punishment.

One last distinction is that the offense of promoting prostitution is investigated by the criminal investigation bodies under the supervision of a prosecutor working in the prosecutor's offices attached to the courts, while the offence of human trafficking is within the competence of the prosecutor within the Department of Investigation of Organized Crime and Terrorism Offenses, specialized unit created within the Public Ministry, with attributions throughout the country for the control of organized crime and terrorism.

\section{CONCLUSIONS}

Even if the level of education of the population is ascending, poor social-economic conditions lead to the adventuring of people in the unknown by pursuing a better living, where they fall prey to the action of traffickers.

We believe that greater media promotion of ways to prevent human trafficking would be helpful. Also, implementing programs in schools and presenting ways to seize victims of traffickers would make the percentage of human trafficking to decrease.

\footnotetext{
${ }^{18}$ ICCJ , United Sections, Dec. no.XVI from $19^{\text {th }}$ of March 2007,appeal in the interest of the law on the application of criminal provisions of art. 329 from the Criminal Code and art. 12 and 13 from Law no. 678/2001 regarding the prevention and control of human trafficking, in the Official Gazette of Romania no. 542 from $17^{\text {th }}$ of July 2008.

${ }^{19}$ I. Gârbuleț, Human trafficking, UniversulJuridic ed., Bucharest, 2010, p. 53
} 


\section{Vlad-Alexandru Porumb}

It is true that prostitution is one of the oldest trades in the world and is regulated in a wide variety of ways, ranging from punishment to complete legalization, it could be more easily controlled by increasing the activity of competent bodies and re-educating the people practicing this profession so that they can carry out other activities to ensure their everyday living.

These preventive methods could reduce both the number of people who become the prey of this immoral act and the work of the designated people to deal with these cases.

The emotional and psychological impact on people who become victims of human trafficking and implicitly of involuntary prostitution / pornography is so powerful that it requires a long period of mental recovery and social rehabilitation of both the victim and his / her family.

\section{BIBLIOGRAPHY:}

M.Focault, The History of sexuality, vol. 3 ,Univers edition, Bucharest, 2005

I. Gârbuleţ, Human trafficking, UniversulJuridic ed., Bucharest, 2010

C. Barsan, European Convention of Man's Rights. Remarks on articles, vol. I, Rights and freedom, All Beck ed., Bucharest, 2007

I. Lascu, Indictments regarding human trafficking, in RDP (Criminal Law Magazine) no. 3/2002

Gh. Mateuț, V.E. Petrescu, N. Ștefăroi, A. Prună, C. Luca, Human trafficking. Offender. Victim. Offence. Social Alternative Association ed., Iași, 2005

G. Antoniu, Remarks in the Criminal Code. Special section. ȘtiințificășiEnciclopedică ed., Bucharest, 1975

Romanian Explanatory Dictionary, IInd ed., EnciclopedicUnivers ed., Bucharest, 1996

The Official Gazetteof Romania:

- Order of the Ministry of Justice no. 1806/2004

- Government Order no. 299/2003

- Law no. 678/2001 - regarding the prevention and control of human trafficking

- Law no. 302/2004 - regarding the international legal cooperation in criminal matters

- Law no. 211/2004 - regarding certain measures for insuring the protection of victims of this offence

- ICCJ, United Sections, Dec. no.XVI from 19th of March 2007

Criminal Code - Special section 